ISSN: 2536-5339

\title{
Yozgat Bozok Üniversitesi Beden Eğitimi ve Spor Yüksekokulu Özel Yetenek Giriş Sınavına Katılan Adayların Sınav Hakkındaki Görüşleri: Nitel Bir Çalışma
}

\author{
Çağdaş CAZ
}

\author{
Yozgat Bozok Üniversitesi, Beden Eğitimi ve Spor Yüksekokulu, YOZGAT
}

Künye: Caz, Ç. (2018). Yozgat Bozok Üniversitesi Beden Eğitimi ve Spor Yüksekokulu Özel Yetenek Giriş Sınavına Katılan Adayların Sınav Hakkındaki Görüşleri: Nitel Bir Çalışma. Gaziantep Üniversitesi Spor Bilimleri Dergisi, 3(4): 138-152.

\section{Öz}

Spor ve eğitim toplumsal ve bireysel yapının gelişmesinde birbirini tamamlayan iki unsurdur. Bireyler sağlıklı bir yaşam içerisinde istenilen eğitime ulaşarak gelişimlerini sağlayacak ve sağlam toplum yapısına katkı yapacaklardır. Eğitimin yapıtaşlarından olan yükseköğretim kurumları ve bu çatı içerisinde yer alan spor eğitimi veren yükseköğretim kurumları, birçok birey açısından popüler hale gelmiştir. Bu bakımdan, Beden Eğitimi ve Spor Yüksekokulu özel yetenek sınavına katılan adayların sınav hakkındaki görüşlerinin incelenmesi amaçlanmıştır. Araştırmada, nitel araştırma yöntemlerinden özel durum çalışması kullanıımıştır. Çalışma grubunu, Yozgat Bozok Üniversitesi, Beden Eğitimi ve Spor Yüksekokulu özel yetenek sınavına başvuru yapan 18 birey (yaş aralığı 18-33) oluşturmaktadır. Veri toplama aracı olarak, araştırmacı tarafından oluşturulan yarı yapılandırılmış görüşme formu kullanılmıştır. Bu form, toplamda on bir sorudan oluşmaktadır. Araştırmada elde edilen bulgular, içerik analizi kullanılarak yorumlanmıştır. Özel yetenek sınavına başvuran adayların sınava ilişkin görüşleri belirlenen alt temalarda incelenmiştir. Mevcut çalışmada, adaylar sınav için çift hak verilmesinin doğru olduğunu ifade etmişlerdir. Ayrıca, şehir dışından gelen adaylar için yorgunluk hissetmek, konaklama sorunu yaşamak, sınav süresini beklerken moral ve motivasyonun düşmesi gibi faktörlerin rol oynadığı saptanmıştır.

\section{Orijinal Makale}

Yayın Bilgileri

Gönderi Tarihi: 23.10.2018

Kabul Tarihi: 27.11.2018

Yayın Tarihi: 28.12.2018

Sorumlu Yazar

e-mail: cazcagdas@gmail.com

DOI: $10.31680 / g a u n j s s .474090$

Anahtar Kelimeler: Özel yetenek sınavı, Beden Eğitimi ve Spor Yüksekokulu, Bozok Üniversitesi

\section{The Opinions Of Candidates Who Join Special Talent Examination in Yozgat}

\section{Bozok University School Of Physical Education And Sport: A Qualitative Study}

\begin{abstract}
Sports and education are two complementary elements in the development of the social and individual structure. Individuals will reach their desired education in a healthy life and will contribute to the development of a healthy society. The higher education institutions that are the building blocks of education and the higher education institutions that provide sports education in this roof have become popular regarding many individuals. In this term, it is aimed to examine the opinions of the exam the candidates participating in the special talent exam of the School of Physical Education. In the study, the case study of qualitative research methods was used. The study group consisted of 18 individuals (age range 18-33) who applied for the special ability test at Yozgat Bozok University, School of Physical Education and Sports. As a data collection tool, a semi-structured interview form created by the researcher was used. This form consists of eleven questions in total. Findings obtained in the study were interpreted using content analysis. The opinions of the candidates who have applied for the examination have been examined in the sub-themes determined. In the present study, candidates stated that it is right to give them second rights for the exam. Also, for the candidates coming from outside the city, it was determined that factors such as feeling tiredness, experiencing accommodation problems, falling morale and motivation while waiting for the exam period played a role.
\end{abstract}

\section{Original Article}

\section{Article Info}

Received: 23.10 .2018

Accepted: 27.11 .2018

Published: 28.12.218

\section{Corresponding Author}

e-mail: cazcagdas@gmail.com

Key Words: Special Ability Test, School of Physical Education and Sports, Bozok University 


\section{Giriş}

Toplumu değiştirme dönüştürme etkisine sahip kurumların başında üniversiteler gelmektedir (Güllü ve Yenel, 2015). Yükseköğretim bünyesinde yer alan ve eğitim-öğretim faaliyetinde bulunan kurumlar için yapılan seçme ve yerleştirme sınavları, adaylar açısından büyük bir öneme sahiptir. Adaylar hakkında verilecek kararların doğru olması, bu bireylerin başarı ve yeteneklerine göre eğitim almalarını sağlayacak, bu vesile ile ülkemizin gelişmişlik seviyesi artacaktır (Güzeller ve Kelecioğlu, 2006). Bu bağlamda eğitimin temel amaçlarından biri de düşünüp eleştirebilen, çalışkan, kişiliği ve sosyal ilişkileri ile bütün olarak gelişmiş insanlar yetiştirebilmektir (Yenilmez ve Duman, 2008). Eğitimin temelinde yer alan bu olumlu olgular neticesinde üniversitelerimizin beden eğitim ve spor yüksekokulu bölümleri ile eğitim fakültelerinin beden eğitimi ve spor öğretmenliği bölümlerine özel yetenek sınavları ile öğrenci alınmaktadır. Her yıl gerçekleştirilen özel yetenek sınavlarının temel amacı, sınavlara başvuran adaylar arasından yetenekli ve başarılı olabilecek öğrencileri seçebilmektir (Peker, 2003). Öğrenci Seçme ve Yerleştirme Merkezinin belirlemiş olduğu Yükseköğretim Programları ve Kontenjan Kılavuzu'nda belirtilen esaslara bağlı kalınarak üniversiteler kendi sınav yöntemlerini belirleyebilmektedirler (Koparan ve Öztürk, 2008). Ancak, her üniversite için sabit bir sınav uygulanış yöntemi bulunmamaktadır. Her üniversite kendi olanakları doğrultusunda sınav şeklini belirlemektedir (Başpınar ve Öğüş, 1997; İnce ve ark., 2004). Üniversitelerin özel yetenek gerektiren program uygulamakta olan bölümlerine; öğrenci alımları, özel yetenek sınavları ile gerçekleşmektedir. Bu sınavlar ve sonuçları her yıl yaz aylarında ve üniversite seçme sınavının açıklanmasından sonra, özel yetenek gerektiren program bulunan fakülte, bölüm, anabilim dalı, yüksek okul vb. birimlerinin olduğu üniversitelerin kendi belirledikleri tarihte ve yine üniversitelerin kendileri tarafından yapılmakta ve açıklanmaktadır (Ece, 2007).

Toplumun geleceğini şekillendirecek olan gençlerin hem zihinsel hem de fiziksel açıdan sağlıklı bireyler olarak yetişmesi toplumun geleceği için çok önemlidir (Göksel ve Caz, 2016). Bu bağlamda bireyler için hayatın hemen hemen her anında ve aşamasında yer edinen spor ve sportif faaliyetler, gün geçtikçe sağlık ve mesleki açıdan önem kazanmaya başlamıştır. Özellikle meslek edinme noktasında spor ile doğrudan ilişkili olan spor eğitimi veren yükseköğretim kurumları giriş sınavları da bireyler tarafından yoğun talep ile karşı karşıya kalmıştır. Gün geçtikçe artan sayıları ile beden eğitimi ve spor yüksekokulları ve spor bilimleri fakülteleri, verilen eğitim- 
öğretim sonrasında meslek edindirme özelliği nedeniyle yoğun bir şekilde talep edilmektedir. Her üniversitenin öğrenci seçim kriterleri kısmi olarak benzer olsa da birçok özelliği ile birbirinden ayrılmaktadır. Her yıl düzenlenen özel yetenek giriş sınavları, adaylar açısından önem arz etmekte ve sınavın uygulanışı, işleyişi gibi konular da merak edilir duruma gelmiştir. Bu düşüncelerden hareketle mevcut çalışmada, Beden Eğitimi ve Spor Yüksekokulu (BESYO) özel yetenek sınavına katılan adayların sınav hakkındaki görüşlerinin incelenmesi amaçlanmıştır. Bu amaç doğrultusunda elde edilen sonuçlar ile adayların gözünden sınav hakkındaki düşünceler netlik kazanmış olacaktır. Ayrıca, spor bilimleri alanına kaynak oluşturması bakımından da katkı sağlayacağı düşünülmektedir.

\section{Yöntem}

\section{Araştırma Modeli}

Mevcut araştırmada, özel yetenek giriş sınavına başvuran adayların sınav hakkındaki görüşlerini belirlemek için nitel araştırma yaklaşımı benimsenerek, durum çalışması yapılmıştır. Nitel araştırmalarda gözlem, görüşme veya doküman analizi gibi nitel veri toplama yöntemlerinin kullanıldığı, düşüncelerin gerçekçi ve bütüncül bir biçimde ifade edilmesine yönelik bir süreç izlenmektedir. Nitel durum çalışmalarında ise, incelenmek istenen durum ya da durumlar derinlemesine araştırılarak bütüncül bir yaklaşımla değerlendirilir ve ilgili durumu nasıl etkilediği ya da etkileyeceği ifade edilir (Yıldııım ve Şimşek, 2005).

Araştırmada veri toplama aşamasında görüşme yöntemlerinden biri olan "Yarı Yapılandırılmış Görüşme Tekniği” kullanılmıştır. Bu yöntem, ne çok katı ne de çok esnek olmayıp, iki uç arasında yer almaktadır (Karasar, 1995).

\section{Araştırma Grubu}

Çalışmaya, 2018-2019 eğitim-öğretim yılı Yozgat Bozok Üniversitesi Beden Eğitimi ve Spor Yüksekokulu özel yetenek giriş sınavı için başvuran ve yaşları 18-33 yaş arasında değişen 18 aday katılım göstermiştir. Bu adaylar ile ilgili kişisel bilgiler Tablo 1'de sunulmuştur.

\section{Veri toplama aracı}

Veriler, araştırmacı tarafından oluşturulan "Yarı Yapılandırımış Görüşme Formu" yardımı ile toplanmıştır. Bu doğrultuda araştırmacı tarafından hazırlanan ve 
toplamda 11 sorudan (demografik sorular, sınava dair oluşturulan sorular) oluşan veri toplama formu, sınava başvuran adaylar ile yapılan ve sınav hakkında genel düşünceleri içeren bir ön görüşme sonrasında hazırlanmıştır. Hazırlanan veri toplama formu, alanda uzman akademisyenler ile görüşüldükten sonra son hali verilerek hazır hale getirilmiştir.

\section{Verilerin toplanması ve analizi}

Veriler, yarı yapılandırımış görüşme formu ile toplanmıştır. Araştırmaya katılan adaylar ile bir ön görüşme yapılarak kendilerine çalışma hakkında bilgi verilmiştir. Araştırmaya katılım gönüllülük esasına göre gerçekleştirilmiştir. Görüşmeler yüz yüze görüşme şeklinde yürütülmüş ve adayların konuya ilişkin ifadeleri araştırmacı tarafından aynı anda yazıya geçirilmiştir. Görüşmeler tamamlandıktan sonra elde edilen yazılı kayıtlar, bilgisayar ortamına aktarılmıştır. Aktarımı yapılan ifadeler, soru bazında birer sınıflama yapılarak içerik analizi için hazır hale getirilmiştir. Yapılan içerik analizi ile adaylar tarafından dile getirilen görüşlerden alıntılar yapılmıştır. Alıntı yapılan görüşün sonuna araştırmanın kaçıncı adayına ait olduğunu ve adayın yaşını belirtmek için rakamlar yazılmıştır. Örneğin (3-18); araştırmaya 3. sırada katılan 18 yaşındaki adayı simgelemektedir.

\section{Bulgular}

Tablo 1. Özel Yetenek Sınavına Başvuru Yapan Adaylar İle İlgili Kişisel Bilgiler

\begin{tabular}{cccc}
\hline Aday & Yaş & Cinsiyet & BESYO Kursuna Katılma Durumu \\
\hline A1 & 21 & Erkek & Evet \\
\hline A2 & 18 & Kadın & Evet \\
\hline A3 & 18 & Kadın & Evet \\
\hline A4 & 19 & Kadın & Evet \\
\hline A5 & 22 & Kadın & Evet \\
\hline A6 & 19 & Erkek & Evet \\
\hline A7 & 18 & Erkek & Evet \\
\hline A8 & 19 & Kadın & Evet \\
\hline A9 & 19 & Kadın & Evet \\
\hline A10 & 18 & Kadın & Evet \\
\hline A11 & 20 & Erkek & Evet \\
\hline A12 & 20 & Erkek & Evet \\
\hline A13 & 18 & Erkek & Evet \\
\hline A14 & 19 & Erkek & Evet \\
\hline A15 & 18 & Kadın & Hayır \\
\hline A16 & 18 & Kadın & Evet
\end{tabular}


Tablo 1'de BESYO Özel Yetenek sınavlarına katılın adayın yaş, cinsiyet ve BESYO hazırlık kursuna katılıp katılmama durumu ile ilgili bilgilere yer verilmiştir. Tablo 1'e göre, 18-33 yaşları arasında çalışmaya katılan 18 adayın 9'u erkek, 9'u kadındır. Bu 18 adaydan 2'si hazırlık kursuna katıım göstermemiştir.

Tablo 2. Adayların BESYO Sınavlarına Katılım Hakkı İle İlgili Görüşleri

\begin{tabular}{ccl}
\hline Aday & $\begin{array}{c}\text { Kaç Hak } \\
\text { Verilmeli }\end{array}$ & \multicolumn{1}{c}{ Nedeni } \\
\hline A1 & Çift & Sınav Yerine Ulaşım Zorluğu-Sınav Salonuna Yabancılık \\
\hline A2 & Çift & Sınav Heyecanı \\
\hline A3 & Çift & Hataları Görme Ve Telafi Etme \\
\hline A4 & Çift & Sınav Heyecanı Ve Hataların Telafisi \\
\hline A5 & Çift & Sınav Heyecanı Ve Stresin Var Olması \\
\hline A6 & Çift & Sınav Heyecanı Ve Hataların Görülmesi \\
\hline A7 & Çift & Sınav Heyecanı Ve Hataların Görülmesi \\
\hline A8 & Çift & Sınav Heyecanı \\
\hline A9 & Çift & Sınav Heyecanı \\
\hline A10 & Çift & Vücudun Isınması Ve Sınav Heyecanı \\
\hline A11 & Çift & Hataların Görülmesi \\
\hline A12 & Çift & Hataların Görülmesi \\
\hline A13 & Çift & Hataları Görme Ve Telafi Etme \\
\hline A14 & Çift & Sınav Heyecanı \\
\hline A15 & Çift & Sınav Heyecanı Ve Hataların Telafisi \\
\hline A16 & Çift & Sınav Heyecanı Ve Stresin Var Olması \\
\hline A17 & Çift & Tecrübe Kazanmak \\
\hline A18 & Çift & Sınav Heyecanı Ve Hataların Telafisi \\
\hline
\end{tabular}

Araştırmaya katılan 18 adayın tümü, sınavda çift hak verilmesini istemektedir. $\mathrm{Bu}$ adayların çift hak istemelerinin nedenleri şu şekilde sıralamıştır; sınav yerine ulaşım zorluğu-sınav salonuna olan yabancılık, hataları görme ve telafi etmek, sınav heyecanın var olması, stresin ortaya çıkması, vücudun ısınması ve tecrübe kazanmaktır.

Örneğin; (A5-22) bu konudaki görüşlerini şu şekilde belirtmiştir: "Çift hak verilmesi daha doğrudur. Çünkü aday heyecan ve stres yaşayarak ilk hakkında istenilen performansı sergileyememe durumu olabilir. Bu nedenle her aday ikinci hakkına sahip olmalı".

(A3-18) ise şu ifadelerde bulunmuştur:

"Çift hak verilmeli. Adaylar, ilk haklarında yaşadıkları heyecan ve yapacakları hataları, ikinci haklarında telafi edebilirler". 
Tablo 3. Adayların Koordinasyonun Son Kısmında Fotosele Doğru Koşarken Yavaşlama/Hız Kesme İle İlgili Görüşleri

Aday Adayların koordinasyonda bitiş fotoseline yaklaşırken hızını kesme nedeni

\begin{tabular}{ll}
\hline A1 & Parkurun uzun olması \\
\hline A2 & Zihinde Parkurun/koordinasyonun bittiğini düşünmeleri \\
\hline A3 & Meydana gelen fiziksel yorgunluk ve buna bağlı olarak zihinde bitirmek \\
\hline A4 & Yorgunluğun oluşması, buna bağlı olarak nefes alış verişinde düzensizlik \\
\hline A5 & Hızlı başlangıç yapılan Parkurun/koordinasyonun sonuna doğru adayın gücünün azalması \\
\hline A6 & Parkurun/koordinasyonun bittiğini düşünmek \\
\hline A7 & $\begin{array}{l}\text { Fotoselin konumlandığı yerin duvar ya da salonun bitimine yakın olması nedeniyle bir } \\
\text { yerlere çarpma korkusu }\end{array}$ \\
\hline A8 & Psikolojik açıdan parkurun/koordinasyonun bittiğini düşünmek \\
\hline A9 & Bacakların yorulması, nefes zorluğu \\
\hline A10 & Kondisyon eksikliği ve nefes zorluğu \\
\hline A11 & Meydana gelen fiziksel yorgunluk \\
\hline A12 & Meydana gelen fiziksel yorgunluk ve buna bağlı olarak zihinde bitirmek \\
\hline A13 & Meydana gelen fiziksel yorgunluk ve Fotoselin konumlandığı yerin duvar ya da salonun \\
& bitimine yakın olması nedeniyle bir yerlere çarpma korkusu \\
\hline A14 & Kondisyon eksikliği \\
\hline A15 & Psikolojik açıdan parkurun/koordinasyonun bittiğini düşünmek \\
\hline A16 & Heyecanın var olması \\
\hline A17 & Bacakların yorulması \\
\hline A18 & Dayanıklılığın iyi düzeyde olmaması \\
\hline
\end{tabular}

Araştırmaya katılan adaylar, parkurun sonuna konumlanan bitiş fotoseline yaklaşırken hızının kesmeleri hakkındaki düşüncelerini tablo 3'te belirtmişlerdir. Genel olarak bu kısımda hızlarını kesmeye, bireylerin kondisyonlarının yeterli olmaması ve parkurun bittiğini düşünmeleri sebebiyet verdikleri ifade edilmektedir.

Örneğin; (A8-19) bu konudaki görüşlerini şu şekilde belirtmiştir:

"Bence tamamiyle psikolojik bir durum. Fotoseli görüyoruz ve parkurun bittiğini düşünüyoruz, istemsiz bir şekilde yavaşlama oluyor"

(A13-18) ise şu ifadelerde bulunmuştur:

"Sonlara yaklaştıkça yorgunluk büyük etken ve bitiş fotoseli genelde duvara yakın konuluyor. Bizlerde duvara çarpmanın korkusu ile yavaşlıyoruz" 
Tablo 4. Adayın Fotoseli Uçarak Kesmesi İle İlgili Görüşleri

\begin{tabular}{lll}
\hline Aday & Uçarak kesmek doğru mu? & Nedeni \\
\hline A1 & Evet & Süre açısından avantaj sağlar \\
\hline A2 & Hayır & Hızı keser, süre açısından avantaj sağlamaz \\
\hline A3 & Hayır & Hızı keser, süre açısından avantaj sağlamaz \\
\hline A4 & Evet & Uzun boylu olanın kol boyunun uzun olmasından dolayı \\
\hline A5 & Hayır & Bireyin boynunun kısa olması, uzuvların kısa olması \\
\hline A6 & Evet & Süre açısından avantaj sağlar \\
\hline A7 & Hayır & Hızı keser, süre açısından avantaj sağlamaz \\
\hline A8 & Hayır & Hızı keser, süre açısından avantaj sağlamaz \\
\hline A9 & Hayır & Koşarak kesmek daha avantajlı \\
\hline A10 & Evet & Süre açısından avantaj sağlar \\
\hline A11 & Hayır & Hızı keser, süre açısından avantaj sağlamaz \\
\hline A12 & Hayır & Hızı keser, süre açısından avantaj sağlamaz ve fiziksel \\
& & sakatlık meydana gelebilir \\
\hline A13 & Hayır & Hızı keser, süre açısından avantaj sağlamaz ve fiziksel \\
& & sakatlık meydana gelebilir \\
\hline A14 & Hayır & Hızı keser, süre açısından avantaj sağlamaz \\
\hline A15 & Hayır & Hızı keser, süre açısından avantaj sağlamaz \\
\hline A16 & Hayır & Hızı keser, süre açısından avantaj sağlamaz \\
\hline A17 & Hayır & Hızı keser, süre açısından avantaj sağlamaz \\
\hline A18 & Hayır & Hızı keser, süre açısından avantaj sağlamaz \\
\hline
\end{tabular}

Araştırmaya katılan adayların fotoseli uçarak kesmeleri hakkındaki görüşleri irdelendiğinde; bireyin hızını keser, süre açısından avantaj sağlamaz, Bireyin boynunun kısa olması, uzuvların kısa olması düşünceleri hâkim olmaktadır.

Örneğin; (A12-20) bu konudaki görüşlerini şu şekilde belirtmiştir:

"Hayır bulmuyorum. Nedeni ise, uçtuktan sonra fiziksel olarak sakatlık meydana gelebilir."

(A6-19), şu ifadelerde bulunmuştur: "Avantaj sağlar, fakat kişiden kişiye göre değişir. Misal boyu kısa olanlar için biri için süre kaybı açısından sorun olabilir ".

(A2-18), "Hayır doğru bulmuyorum. Uçarak kesmek kişinin hızını keser, bu nedenle koşarak kesmek daha mantıkı" şeklinde belirtmiştir.

(A13-18) ise, "Doğru bulmuyorum, çünkü uçarak kesmek risk taşımaktadır. Aday fotoseli kesmeyebilir" ifadelerini kullanmıştır. 
Tablo 5. Adayların Koordinasyonda Önceki Adayı İzleme İle İlgili Görüşleri

\begin{tabular}{lcl}
\hline Aday & $\begin{array}{c}\text { Bireyleri izlemek } \\
\text { avantajlı mı? }\end{array}$ & Nedeni \\
\hline A1 & Evet & Parkuru analiz etmek açısından iyi olur \\
\hline A2 & Evet & Parkurda yer alan istasyonlarda hataları̈ görmek \\
\hline A3 & Evet & Parkurda yer alan istasyonlarda hataları görmek \\
\hline A4 & Evet & Parkurda yer alan istasyonlarda hataları̈ı̈̈rmek \\
\hline A5 & Evet & Hareketlerin nasıl daha iyi yapılacağını görmek \\
\hline A6 & Evet & Hareketlerin nasıl daha iyi yapılacağını görmek \\
\hline A7 & Evet & Parkurda yer alan istasyonlarda hataları̈ı̈̈rmek \\
\hline A8 & Evet & Parkurda yer alan istasyonlarda hataları görmek \\
\hline A9 & Evet & Parkurda yer alan istasyonlarda hataları̈ görmek \\
\hline A10 & Evet & Hareketlerin nasıl daha iyi yapılacağını görmek \\
\hline A11 & Evet & Hareketlerin nasıl daha iyi yapılacağını görmek \\
\hline A12 & Evet & Parkurda yer alan istasyonlarda hataları görmek, hareketleri daha iyi \\
& & yapabilmek \\
\hline A13 & Hayır & Heyecan arttırır, stres yaratır \\
\hline A14 & Evet & Parkurda yer alan istasyonlarda hataları görmek \\
\hline A15 & Evet & Parkurda yer alan istasyonlarda hataları̈ görmek \\
\hline A16 & Evet & Hareketlerin nasıl yapıldı̆ını görmek, hataları tespit etmek \\
\hline A17 & Evet & Parkurda yer alan istasyonlarda hataları görmek \\
\hline A18 & Evet & Parkurda yer alan istasyonlarda hataları̈ görmek, hareketleri daha iyi \\
& & yapabilmek \\
\hline
\end{tabular}

Araştırmaya katılan adayların koordinasyona sizden önce çıkan adayı izlemeniz sizin için herhangi bir konuda avantaj sağlar mı? hakkındaki görüşleri irdelendiğinde; Parkuru analiz etmek açısından iyi olur, Hareketlerin nasıl daha iyi yapılacağını görmek, Parkurda yer alan istasyonlarda hataları görmek şeklinde düşünceler ifade edilmiştir.

Örneğin; (A2-18) bu konudaki görüşlerini şu şekilde belirtmiştir:

“Tabi ki sağlar, Çünkü bizden önce parkura çıkan adayı gözlemlemiş oluyoruz.

Yapılan hataları görme şansımız oluyor".

(A6-19), şu ifadelerde bulunmuştur:

"Sağlar çünkü parkuru daha önce sınav salonunda görmedik. İstasyonların ölçülerini, sahanın zeminini birebir test etme şansımız olmadı. Bu nedenle, benden önce çıkan adayı izleyerek hareketlerin nasıl yapıldığını görmek iyi oluyor”. 
Tablo 6. Adayların sınav öncesinde, sınavda görevli olan hocalara ait tutum ve davranışların sınav performansına etki durumu ile ilgili görüşleri

\begin{tabular}{|c|c|c|}
\hline Aday & $\begin{array}{c}\text { Akademisyenlerin } \\
\text { sınav esnasındaki } \\
\text { tutum ve davranışları } \\
\text { performansı etkiler } \\
\text { mi? }\end{array}$ & Nedeni \\
\hline A1 & Evet & $\begin{array}{l}\text { Var olan stres ve heyecana ek olarak olumlu veya olumsuz } \\
\text { davranışlar etki eder }\end{array}$ \\
\hline A2 & Evet & Olumsuz tutum ve davranışlar, performansa yansır \\
\hline A3 & Evet & Heyecan ve morale etki eder \\
\hline A4 & Evet & Performansa ve düşüncelere etki etmektedir \\
\hline A5 & Evet & Moral ve motivasyona etki edecektir \\
\hline A6 & Evet & Stres ve gerginliğe yol açar, performansı etkiler \\
\hline A7 & Evet & Olumsuz tutum ve davranışlar, performansa yansır \\
\hline A8 & Evet & Olumlu davranışlar, morali yükseltecek ve performansı arttıracak \\
\hline A9 & Evet & $\begin{array}{l}\text { Var olan stres ve heyecana ek olarak olumlu veya olumsuz } \\
\text { davranışlar etki eder }\end{array}$ \\
\hline A10 & Evet & $\begin{array}{l}\text { Var olan stres ve heyecana ek olarak olumlu veya olumsuz } \\
\text { davranışlar etki eder }\end{array}$ \\
\hline A11 & Evet & $\begin{array}{l}\text { Var olan stres ve heyecana ek olarak olumlu veya olumsuz } \\
\text { davranışlar etki eder }\end{array}$ \\
\hline A12 & Evet & Olumlu davranışlar, morali yükseltir ve stresi düşürür \\
\hline A13 & Evet & $\begin{array}{l}\text { Var olan stres ve heyecana ek olarak olumlu veya olumsuz } \\
\text { davranışlar etki eder }\end{array}$ \\
\hline A14 & Evet & Olumsuz tutum ve davranışlar, performansa yansır \\
\hline A15 & Evet & $\begin{array}{l}\text { Olumlu davranışlar, morali yükseltir ve stresi düşürür ya da tam } \\
\text { tersi }\end{array}$ \\
\hline A16 & Evet & Motivasyona etki eder \\
\hline A17 & Hayır & Zihinsel olarak iyi hazırlanmış birini etkilemez \\
\hline A18 & Evet & Stresi arttırabilir, hataya sürükler \\
\hline
\end{tabular}

Araştırmaya katılan adayların sınav öncesinde, sınavda görevli olan hocaların size karşı tutum ve davranışları, sınavda göstereceğiniz performansı etkileyeceğini düşünüyor musunuz? hakkındaki görüşleri irdelendiğinde; Olumsuz tutum ve davranışlar, performansa yansır, Olumlu davranışlar, morali yükseltir ve stresi düşürür, Zihinsel olarak iyi hazırlanmış birini etkilemez gibi düşünceler hakim olmuştur.

Örneğin; (A1-21) bu konudaki görüşlerini şu şekilde belirtmiştir:

"Çok doğru bir tespit. Sınav öncesi stres ve heyecan olduğu için performansım zaten etkilenmektedir. Bunun üzerine hocaların da baskısı olursa daha da demoralize olunur". 
(A7-18) ise şu ifadelerde bulunmuştur:

"Görevli hocaların olumsuz tutum ve davranışları benim ya da diğer adayların performanslarını kesinlikle etkileyecektir. Bu nedenle karşılıklı etkileşimin önemli olduğunu düşünüyorum".

Tablo 7. Adayların Koordinasyon Sınav Zamanı Ve Bu Zamanın Performansa Etki Durumu İle İlgili Görüşleri

\begin{tabular}{lcl}
\hline Aday & $\begin{array}{c}\text { Koordinasyon sınavının } \\
\text { hangi vakit (sabah-öğlen- } \\
\text { akşam) olmasını } \\
\text { istersiniz? }\end{array}$ \\
\hline A1 & Sabah & Fiziksel olarak daha dinç ve hazır olmak \\
\hline A2 & Sabah & Fiziksel olarak daha dinç ve hazır olmak \\
\hline A3 & Fark etmez & Fiziksel ve zihinsel olarak hazır olmak \\
\hline A4 & Öğlen & Sabah kahvaltı sonrası vücudun hazır olması \\
\hline A5 & Sabah & Fiziksel olarak daha dinç ve hazır olmak \\
\hline A6 & Öğlen & Kişinin hazır ve iyi hissetmesi \\
\hline A7 & Öğlen & Vücut daha dinlenmiş ve hazır olur \\
\hline A8 & Sabah & Fiziksel olarak daha dinç ve hazır olmak \\
\hline A9 & Sabah & Fiziksel olarak daha dinç ve hazır olmak \\
\hline A10 & Sabah & Fiziksel olarak daha dinç ve hazır olmak \\
\hline A11 & Sabah & Fiziksel olarak daha dinç ve zinde olmak \\
\hline A12 & Öğlen & Vücut daha dinlenmiş ve hazır olur \\
\hline A13 & Sabah & Fiziksel olarak daha dinç ve hazır olmak \\
\hline A14 & Fark etmez & Fiziksel ve zihinsel olarak hazır olmak \\
\hline A15 & Sabah & Fiziksel olarak daha dinç ve hazır olmak \\
\hline A16 & Akşam & Hava şartlarının (sıcaklık), ortam ışıklarının uygun olması \\
\hline A17 & Fark etmez & Fiziksel ve zihinsel olarak hazır olmak \\
\hline A18 & &
\end{tabular}

Araştırmaya katılan adayların koordinasyon sınav zamanının (sabah-öğlenakşam) hangi vakitlerde olmasını istersiniz, bu vaktin performansınıza nasıl bir etkisi vardır? hakkındaki görüşleri irdelendiğinde; Fiziksel olarak daha dinç ve hazır olmak, Kişinin hazır ve iyi hissetmesi, Hava şartlarının (sıcaklık), ortam ışıklarının uygun olması gibi cevaplar alınmıştır.

Örneğin; (A8-19) bu konudaki görüşlerini şu şekilde belirtmiştir:

"Bence sabah olması daha iyidir. Çünkü, ben sabahları daha dinç olduğumu hissediyorum. Bu da koordinasyon dereceme olumlu şekilde etki etmektedir".

(A4-19) şu ifadelerde bulunmuştur: 
"Sabah olması, yemek yiyip gelenler için sorun olabilir. Öğlen olması, en doğru olanıdır. Çünkü yapılan kahvaltıyı sindirmiş oluruz. Kişi daha dinç hisseder. Akşam olması, en sakıncalı olandır, çünkü günün tüm yorgunluğu üstümüzde olacaktır".

(A6-19) ise şu ifadelerde bulunmuştur:

"Öğlen vaktinin olması daha iyi olur. Kişi kendisini o vakitte daha dinç ve güçlü hisseder. En iyi performans sergileyebileceği zamandır".

Tablo 8. Sınavın Şehir Dışında Yapılmasının Adaylar Üzerindeki Olumsuz Etkilerine Yönelik Görüşler

\begin{tabular}{ll}
\hline Aday & Şehir dışından gelmiş olmanın olumsuz etkileri nelerdir? \\
\hline A1 & Yol yorgunluğu, hava şartlarının farklı olması, konaklama sorunu \\
\hline A2 & Yol yorgunluğu, konaklama sorunu, masraf (yol-yeme/içme-konaklama) \\
\hline A3 & Yol yorgunluğu, hava şartlarının farklı olması, konaklama sorunu \\
\hline A4 & Şehri bilmemek, konaklama sorunu \\
\hline A5 & Yol masrafı, sınav başvuru tarihlerine yetişememek \\
\hline A6 & Konaklama sorunu, yol masrafı \\
\hline A8 & Konaklama sorunu, maddi sıkıntı \\
\hline A9 & Yol yorgunluğu, sınav zamanını saatler önce beklemek buna bağlı olarak fiziksel ve \\
\hline A10 & Yol yorgunluğu, şehrin ve okulun fiziksel görüntüsüne adapte olamamak \\
\hline A11 & Yol yorgunluğu \\
\hline A12 & Yol yorgunluğu \\
\hline A13 & Kiziksel yorgunluk, hava şartlarına uyum sağlayamama, konaklama sorunu, \\
\hline A14 & Konaklama sorunu, maddi sıkıntı \\
\hline A15 & Olumsuz etkileri yoktur \\
\hline A16 & Uyku problemi yaşamak \\
\hline A17 & Stres, uykusuzluk duymak, yeme-içme sorunu, yorgunluk yaşamak ve sınavı uzun süre \\
\hline A18 & Keklemek \\
\hline
\end{tabular}

Araştırmaya katılan adayların Sınava şehir dışından gelmiş olmanızın olumsuz etkileri neler olabilir? hakkındaki görüşleri irdelendiğinde; yol yorgunluğu, hava şartlarının farklı olması, konaklama sorunu, maddi sıkıntı şeklince cevaplar verilmiştir. Örneğin; (A2-18) bu konudaki görüşlerini şu şekilde belirtmiştir: "Yol yorgunluğu, kalacak yer açısından sıkıntı yaşamamız, yeme-içme ve yol ücreti açısından sorun yaşamaktayım".

(A16-18), şu ifadelerde bulunmuştur:

"Yorgunluk hissetmenin yanı sıra, sınavın yapılacağı şehir ve sınav saatinin beklendiği süre açısından sorunlar yaşamaktayım". 
(A12-20), şu ifadelerde bulunmuştur:

"Yorgunluk hissi, konaklama sorunu, üniversitenin şehir merkezine olan konumu, bundan dolayı da sınav yerine geçiş aşamasına yaşanan zorluklar".

(A8-19) ise şu ifadelerde bulunmuştur:

"Yol yorgunluğu hissetmek, ayrıca sınav zamanını fazla beklediğimiz için aşırı yorgunluk ve halsizlik yaşanmaktadır".

\section{Tartışma ve Sonuç}

Beden eğitimi ve spor yüksekokulu özel yetenek giriş sınavına başvuran adayların sınav hakkındaki görüşlerinin incelendiği mevcut çalışmada elde edilen veriler analiz edilmiş ve bu kısımda sonuca bağlanmıştır. Çalışmaya katııım gösteren on sekiz adaydan ikisi sınava hazırlık sürecinde BESYO hazırlık kursuna gitmemiş ve bireysel olarak sınava hazırlanmıştır. Adaylar, BESYO sınavlarında hataların telafi edilmesi, ortaya çıkan heyecan ve stresin azalması gibi nedenlerden dolayı çift hak verilmenin daha makul ve doğru olduğunu ifade etmişlerdir. Bu bulgu ile, özel yetenek sınavlarında verilen çift hakkın adaylar açısından avantaj oluşturduğu anlaşılmaktadır.

Adayların bitiş fotoseline doğru koşarken hızını kestikleri ifade edilmiştir. Bu durum adaylar tarafından sınavın son aşamasında yorgunluğun artması, psikolojik olarak parkurun bittiği düşüncesine kapılmak, dayanıklıığın düşük, heyecanın ise yüksek seviyede olması gibi faktörlerin etkili olduğu şeklinde ifade edilmiştir. Bu bulgu neticesinde, adayların sınavlara kondisyon ve mental açıdan daha etkili hazırlanmaları gerekliliği ortaya çıkmaktadır. Bu sayede adaylar sınav esnasında daha etkili ve rahat olacaklardır.

Sınav esnasında adayların fotoseli uçarak kestikleri sorgulandığında, kimi adaylar avantaj kimi adaylar ise dezavantaj sağlayacağını belirtmiştir. Avantaj sağlayacak durumlar içerisinde; süre açısından faydalı olacağı ifade edilirken, dezavantaj sağlayacak durumlar içerisinde ise; adayın hızının düşeceği, adayın zemin ile teması sonrasında fiziksel sakatlık yaşayacağı gibi faktörler ifade edilmiştir. Bu sonuçlar kapsamında genel olarak adayın bir hareketi nizami/doğru yapması ile kendisi açısından faydalı olacağı bilinen bir gerçektir. Bu bağlamda adayların fotoseli uçarak kesmemesinin daha çok avantaj sağlayacağı söylenebilir. 
Adaylar, koordinasyon sınavı esnasında salon içerisinde başka bir adayı izlemenin kendileri için avantajlı olacağını ifade etmişlerdir. Parkurun analiz edilmesi, yapılan hataların görülmesi açısından olumlu olacağı söylenmiş̧ir. Ancak çalışmaya katıın bir aday, salonda başka bir adayı izlemenin kendisinde heyecan ve stres seviyesini arttıracağını dile getirmiştir (A13-Erkek). Genel olarak değerlendirildiğinde, adayların sınav esnasında salon içerisinde birbirlerini izlemesi kendileri açısından fayda sağlayabilecektir. Burada önemli olan bir kavramda zihinde canlandırma (imgeleme)'dır. Bu sayede adaylar parkura çıkmadan hareketleri zihinde canlandıracak ve sınava bir ön hazırlık yapmış olacaklardır.

Sınav öncesi, sınavda görevli akademisyenlerin adaylara karşı olan tutum ve davranışları adayların performansları üzerinde olumlu etki yaratacağı ifade edilmiştir. Genel olacak, adaylarda meydana gelen heyecan ve stresi azaltacağı, motivasyonu arttıracağı yönde ifadelerde bulunulmuştur. Ancak, sınava katılan adaylardan A1733-Erkek, akademisyenlerin sınav esnasında gösterecekleri tutum ve davranışların kendi performansı üzerinde herhangi bir etki yaratmayacağını söylemiştir. Nedeninin ise, sınava zihinsel ve fiziksel olarak iyi bir şekilde hazırlanmanın etkili olacağını belirtmiştir. Sınava hazırlık aşamasında yoğun emek vermenin yanı sıra sınav günü heyecan ve stres yaşayan adayların kendilerini daha iyi hissetmeleri aşamasında etkili olacak olan etkileşim ve iletişim önem kazanmaktadır. Bu nedenle şartlar ne olursa olsun akademisyenlerin, özel yetenek giriş sınavına katılan adaylara sınav öncesi ve sınav esnasına olumlu tutum ve davranışlarda bulunmaları gerekmektedir.

Koordinasyon sınav zamanının sabah/öğlen ya da akşam olmasının adayların performanslarında farklı etkiler yaratacağı ortaya çıkmışıı. Kimi adaylar sabah, kimi adaylar öğlen kimi adaylar ise akşam çıkmanın avantaj sağlayacağını ifade etmiştir. Bu bulgu, sınav zamanın adayların performansında farklı etkiler yarattığını ortaya çıkarmaktadır. Bu duruma salon sıcaklığının, salonun aydınlığının, adayların fizyolojik ve psikolojik yapılarının da etki ettiği söylenebilir.

Sınava şehir dışından gelen adaylar için birçok zorluğun varlığı ortaya çıkmışıı. Adaylar genel olarak şehir dışından gelmenin kendilerinde yarattığı fiziksel ve zihinsel yorgunluktan bahsetmişlerdir. Ayrıca, sınava girecekleri şehirde konaklama sorunun da olduğu ifade edilmiştir. Bu bulgu değerlendirildiğinde adayların sınava girecekleri şehre sınavdan birkaç gün önce gelmeleri, bu sayede fiziksel ve zihinsel olarak dinlenecekleri ve konaklama yapılacak yerin daha erken bir zaman dilimi içerisinde ayarlanması gerektiği ortaya çıkmıştır. 


\section{Kaynaklar}

Başpınar, E., \& Öğüş, E. (1997). Özel Yetenek Sınavı ile Öğrenci Alan Üniversitelerde Puanların Değerlendirilmesi İçin Yöntemler. Beden Eğitimi ve Spor Bilimleri Dergisi, 2(1), 33-50.

Ece, A.S. (2007). The Reflection of Points and Coefficients Taken as Criteria for Special Competence Exams on the Candidates from and out of the Field (Comparative Situation Determination). Mehmet Akif Ersoy Üniversitesi Eğitim Fakültesi Dergisi, 8(13), 1-11.

Göksel, A.G., \& Caz, Ç. (2016). Anadolu Lisesi Öğrencilerinin Beden Eğitimi Dersine Yönelik Tutumlarının İncelenmesi. Marmara Üniversitesi Spor Bilimleri Dergisi, 1(1), 1-9.

Güllü, S., \& Yenel, İ. (2015). Spor Eğitimi Veren Yüksek Öğretim Kurumlarında Görev Yapan Akademisyenlerin Örgütsel Bağlıı̆̆ına İletişimin Etkisi. Sport Sciences, 10(2), 1-15.

Güzeller, C., \& Kelecioğlu, H. (2006). Ortaöğretim Kurumları Öğrenci Seçme Sınavının Sınıflama Geçerliği Üzerine Bir Çalışma. Hacettepe Üniversitesi Eğitim Fakültesi Dergisi, 30, 140-148.

İnce, G., Zülkadiroğlu, Z., \& Budak, D.B. (2004). Çukurova Üniversitesi Beden Eğitimi ve Spor Yüksekokulu Özel Yetenek Sınav Adaylarının I. ve II. Hak Sonuçlarının Karşılaştırılması. SPORMETRE Beden Eğitimi ve Spor Bilimleri Dergisi, 2(1), 510.

Karasar, N. (1995). Bilimsel Araştırma Yöntemi. Ankara: Araştırma eğitim Danışmanlık.

Koparan, Ş., \& Öztürk, F. (2008). Uludağ Üniversitesi eğitim fakültesi beden eğitimi ve spor bölümü özel yetenek sınav verilerinin cinsiyet ve alanlarına göre karşılaştırılması. Gazi Beden Eğitimi ve Spor Bilimleri Dergisi, 8(1), 39-50.

Peker, R. (2003). Uludağ Üniversitesi Eğitim Fakültesi Beden Eğitimi ve Spor Bölümü öğrencilerinin öss ve özel yetenek sınavı puanlarına göre genel akademik başarıları. Uludağ Üniversitesi Eğitim Fakültesi Dergisi, 17(1), 173-184.

Yenilmez, K., \& Duman, A. (2008).Illköğretimde Matematik Başarısını Etkileyen Faktörlere İlişkin Öğrenci Görüşleri. Manas Üniversitesi Sosyal Bilimler Dergisi, 19, 251-268.

Yıldırım, A. \& Şimşek, H. (2005). Sosyal Bilimlerde Nitel Araştırma Yöntemleri Güncelleştirilmiş Geliştirilmiş 5. Baskı. Ankara: Seçkin Yayıncılık. 


\section{Ek 1:}

\section{Görüșme Formu Soruları}

1- BESYO sınavlarında adaylara tek hak mı, çift hak mı verilmelidir? Nedeni nedir?

2- Adaylar genellikle koordinasyonun son kısmında fotosele koşarken yavaşlamaktadırlar/hızını kesmektedirler, sizce nedeni ne olabilir?

3- Adayın fotoseli uçarak kesmesini doğru buluyor musunuz? Bu durum adaya süre açısından avantaj sağlar mı, nedeni ne olabilir?

4- Koordinasyona sizden önce çıkan adayı salon içerisinde izlemeniz sizin için herhangi bir konuda avantaj ya da dezavantaj yaratır mı? Nedeni?

5- Sınav öncesinde, sınavda görevli akademisyenlerin size karşı olan tutum ve davranışları, sınavda göstereceğiniz performansı olumlu ya da olumsuz yönde etkileyeceğini düşünüyor musunuz? Bu ekti ne şekilde olabilir?

6- Koordinasyon sınav zamanının (sabah-öğlen-akşam) hangi vakitte olmasını istersiniz? Bu vaktin performansınızın üzerinde nasıl bir etkisi olabilir?

7- Sınava şehir dışından gelmiş olmanın olumsuz etkileri nelerdir? 